\title{
Angles
}

New Perspectives on the Anglophone World

2 | 2016

New Approaches to the Body

\section{The Brain Without the Body? Virtual Reality, Neuroscience and the Living Flesh}

\section{Marion Roussel}

\section{(2) OpenEdition}

1 Journals

\section{Electronic version}

URL: https://journals.openedition.org/angles/1872

DOI: $10.4000 /$ angles. 1872

ISSN: 2274-2042

\section{Publisher}

Société des Anglicistes de l'Enseignement Supérieur

\section{Electronic reference}

Marion Roussel, "The Brain Without the Body? Virtual Reality, Neuroscience and the Living Flesh", Angles [Online], 2 | 2016, Online since 01 April 2016, connection on 06 June 2022. URL: http:// journals.openedition.org/angles/1872 ; DOI: https://doi.org/10.4000/angles.1872

This text was automatically generated on 6 June 2022.

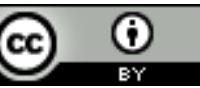

Angles est mise à disposition selon les termes de la Licence Creative Commons Attribution 4.0 International. 


\title{
The Brain Without the Body? Virtual Reality, Neuroscience and the Living Flesh
}

\author{
Marion Roussel
}

\section{Introduction}

1 "The Brain Without the Body" can strike one as a curious title. It reminds us of the concept of the "Body without Organs" developed by French philosophers Gilles Deleuze and Félix Guattari (1980). I am using this expression to refer to a virtual reality environment project named AlloBrain@AlloSphere that was conducted between 2005 and 2009 by architect and artist Marcos Novak. I experienced it myself in March 2014 at the University of California, Santa Barbara.

2 AlloBrain is an immersive environment modelled from Novak's brain MRIs and then extruded in the form of a three-dimensional volume. Its aim is to plunge inside the architect's head, in his cerebral space. Since we all have a brain that is a priori similarly structured, this discovery may be our own as well. However, in this journey beyond the face, we may find it hard to recognise ourselves. What might be familiar and intimate turns out to be, in fact, extremely disturbing and unsettling. Within AlloBrain, I had a strange and particular feeling, an uncanny feeling. The Uncanny, first explored psychologically by psychiatrist Ernst Jentsch and later developed by Sigmund Freud (1919), is a form of anxiety, an uneasiness that relates to familiar things when they appear under a foreign aspect; it emerges when one can no longer recognise what one perceives, when one appears a stranger to oneself; it designates the part of the hidden within us and the fear caused by it.

3 According to Jentsch (1906), the first mark of the Uncanny is a moment of intellectual uncertainty, or the inability to overcome the ambiguity and equivocal nature of meaning. What is this outside meaning that is so disquieting? My aim in this paper is to offer the following hypothesis: the uncanny effect produced by the immersion in 
AlloBrain may result from the confrontation between a naked brain and subjective experience, which seems unable to dispose of a physical body that we inhabit entirely and that inhabits us in return. Thus, what AlloBrain causes may be a real return to the flesh, this lived-in and living flesh, highlighting a proper body that is still foreign to us, because something always resists. Is that thing which cannot be captured by digitisation not the phenomenal "I" itself, the "I" by which we experiment our body and the world? This hypothesis gives us ground to doubt that by uploading our minds in the machine, as some transhuman theorists would have it, we could remain the same.

4 To conduct my analysis, I will first briefly introduce the thoughts that Marcos Novak develops and on which he bases his practice, which is, as we shall see, very experimental. In particular, I will present two virtual reality environments that form the beginnings to AlloBrain, that is to say Dancing with the Virtual Dervish: Worlds in Progress (1991-1994) and Eduction: The Alien-Within (2001). I will then concentrate on AlloBrain. Why did an uncanny feeling seize me when I experienced it? Are we not dealing with a project meant to explain the mind through mere brain matter, not unlike cognitive science or neuroscience? These two questions will structure my analysis, focusing on how this particular virtual reality environment makes us think of the relationships between the mind and the body and between phenomenal consciousness, subjective experience and the physical body. I will address the minduploading fantasy, suggesting that it could be seen as a figure of the crisis of inhabitation denounced by Martin Heidegger after World War II. To conclude, I will question the idea of transhumanity and posthumanity, in relation with the (in)definition of humanity.

\section{Dancing with the Virtual Dervish: Worlds in Progress and Eduction: The Alien-Within: preludes to AlloBrain@AlloSphere}

$5 \quad$ For past thirty years, Marcos Novak (1957) has been developing an experimental and transdisciplinary practice at the meeting point between architecture, art, science, technology and philosophy, to question the becoming of the digitally-enhanced body. His investigations are both philosophical and critical, "regarding the role and the impact of science and technology on culture," and empirical and experimental, concerning "artistic horizons opened up by new science technology" (Novak, 2004). He was one of the first architects, if not the first, to theorise virtual reality environments as architectural spaces and to consider virtual reality devices as matrices for potential worlds. According to Novak, virtual reality environments are experimentation spaces that enable us to push the boundaries of the known world, questioning the possibilities offered by architecture and expanding the field of human senses (1992). In particular, what interests Novak is the exploration of the inner worlds of the self, the unknown and foreign territories concealed in the human psyche. Virtual reality environments are considered as projection and externalisation media of the private mental space, like inverted reflections of this interiority. Novak thus refers to them as "esoscopes," that is to say as viewing instruments, tools to make the invisible worlds hidden within ourselves visible (1996). The virtual environments created by the architect appear both as techniques of dispossession and possession. 
6 In Dancing with the Virtual Dervish: Worlds in Progress, a project conducted between 1991 and 1994, dancers were equipped with head-mounted displays, thereby rendered blind to the outside world. They were plunged into a vision like whirling dervishes, the Sufi mystics who seek to enter a state of trance and to explore consciousness through dance. Dervishes use dancing because it helps promote their motor ability and their mental and emotional unity, allowing them to release the tensions that would otherwise cripple the relationship between mind and body. Dancing with the Virtual Dervish questions this relationship. In this environment, the intention was not to experiment a split between the physical or real body and the mind, rather, the body was established as the true vehicle of exploration. Experimenters dealt with a sensitive, a sensual, even an erotic flesh. Indeed, according to Marcos Novak, in Dancing with the Virtual Dervish, everything hearkened back to incarnation, to the need of the body as first interface and as first medium of any being in the world. For the architect, immersion in virtual reality is not an immersion in a bodiless or disembodied space: it is an immersion which occurs with the body, which cannot be done without the body. However, in the second environment that I will describe, the importance of the physical body appears greatly minimized. This environment is Eduction: The AlienWithin. It was created by Marcos Novak and Marcos Lutyens, a media artist who practices hypnosis.

7 Eduction was presented in 2001 at the 49th Biennial of Art in Venice, in Erice (Sicily) during the second international conference on "Media digitali e psicotecnologie: viaggi nella mente dei mondi virtuali" ${ }^{1}$ and in Florence. Like Dancing with the Virtual Dervish, Eduction was an "esoscope," i.e. a tool to explore the unknown territories of the self. The purpose of this environment was to encounter the other that inhabits our inner dwelling, in short, to meet our alter ego, this "extime" to borrow a term from Jacques Lacan (2006: 249), or Freud's Unheimliche (1919). While in Dancing with the Virtual Dervish we dealt with a true exploring body, here, the issue of the body is dismissed. With Eduction, Novak and Lutyens proposed to submit a volunteer to a state of temporary catalepsy, agnosia and amnesia before projecting him/her in the virtual reality environment. In this experiment, the body was kept almost rigid. It did not move nor occupy the virtual reality space. While Dancing with the Virtual Dervish was based on living flesh - reminding us of Federico Garcia Lorca's statements about the duende ${ }^{2}$ (2007) - , where everything recalled the body - experiencing the deep entanglement of flesh and mind as the first place of a being in the world traversed and possessed by life -, in Eduction, the volunteer no longer had control of his/her body, which was made passive. Only with his/her facial expressions did the volunteer "move", progress, or change the environment through a feedback loop. Facial expressions were captured, translated as data and injected into the virtual reality environment to enable the transformation of this environment.

\section{AlloBrain@AlloSphere}

Eduction: The Alien-Within is interesting because it is clear that Marcos Novak began to focus his attention not on the body as a whole, but on the head and the face. With AlloBrain@AlloSphere, finally, another step was taken since the architect offered a journey beyond the skin, beyond the face, bringing us directly inside a brain. AlloBrain was developed with the assistance of the Brain Mapping Center of the University of 
California in Los Angeles (UCLA), a neuroscience research center that uses brain imaging to understand the structures and functions of the human brain. ${ }^{3}$ Its original aim is not to interpret the data produced and projected in terms of scientific results but to explore the perspectives opened in this regard by virtual reality environments. The Brain Mapping Center establishes itself as a parallel way of investigation to hard science in the understanding of cognitive and perceptual mechanisms of the brain. AlloBrain was made from Marcos Novak's brain MRIs that were extruded in the form of a large-size three-dimensional volume into which one can penetrate.

Figure 1: Marcos Novak, AlloBrain@AlloSphere, 2005

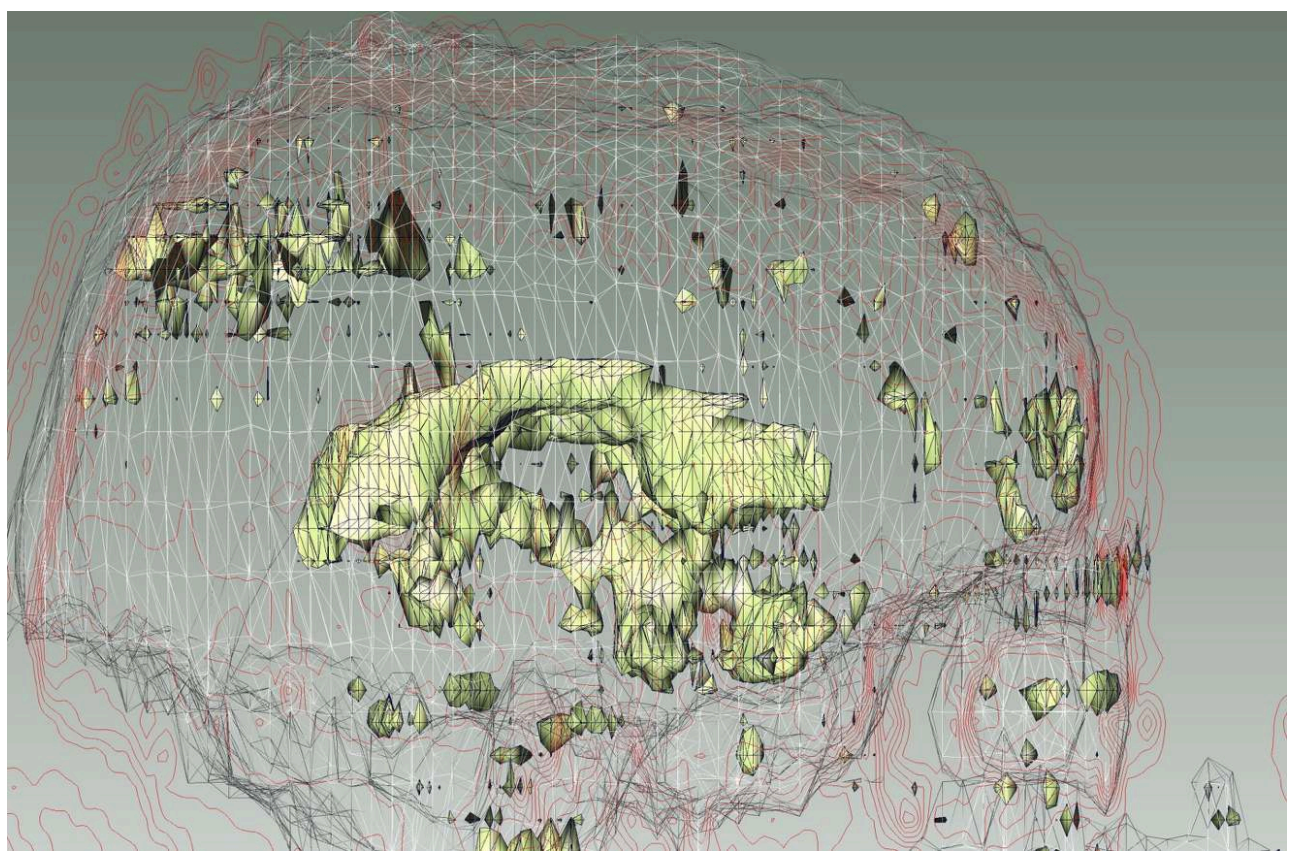

Source: http://cyborglitteraire.com/files/2015/06/ROUSSEL-Marion_Le-cerveau-sanscorps_22.05.15.pdf

9 To engage the audiovisual exploration of this "world," a remote control allows "immersents" (to borrow Char Davies' term) to navigate the datascape. Semiautonomous research agents - twelve in number and represented on the projection surface in the form of small rectangles - are set up, sharing data space with them. These agents are supervised via a second remote that creates a dynamic man-machine interaction interface mode based on pattern recognition and pattern searching. The agents can measure blood flow and their colors change depending on the part of the brain that is being visited, and reports of the data they collect can be sent on request (Wakefield et al., 2009).

10 AlloBrain was the first environment set up for the "AlloSphere" device. Housed at the California Nanosystems Institute building, at the University of California in Santa Barbara, the "Allosphere" experiment is the result of studies conducted by Professor JoAnn Kuchera-Morin for over 25 years. It is intended for immersion and interaction in stereoscopic and pluriphonic virtual environments. Specifically, it is a 10-meter diameter spherical projection surface suspended in a three-level cube. The projection surface consists of two hemispheres between which a bridge can welcome fifteen people who can experience a full immersion, requiring little or no equipment, in 
digitally recreated environments in which one cannot normally go physically. It is a multi- and transdisciplinary tool that has applications in the fields of physics, nanotechnology and neurotechnology, neurophysiology or cosmology, new materials or new media (see illustration below). Artistically speaking, the "AlloSphere" allows for the exploration of avant-garde, experimentation and development of new forms, modes and genres of expression in the fields of cinema, architecture, music, etc. Presenting it at a conference, Kuchera-Morin announced:

Imagine if a team of physicists could stand inside an atom and watch and hear electrons spin. Imagine if a group of sculptors could be inside a lattice of atoms and sculpt with their material. Imagine if a team of surgeons could fly into the brain, as though it was a world, and see tissues as landscapes, and hear blood density levels as music. This is some of the research that you're going to see that we're undertaking at the AlloSphere. (2009a)

Figure 2: View of the AlloSphere

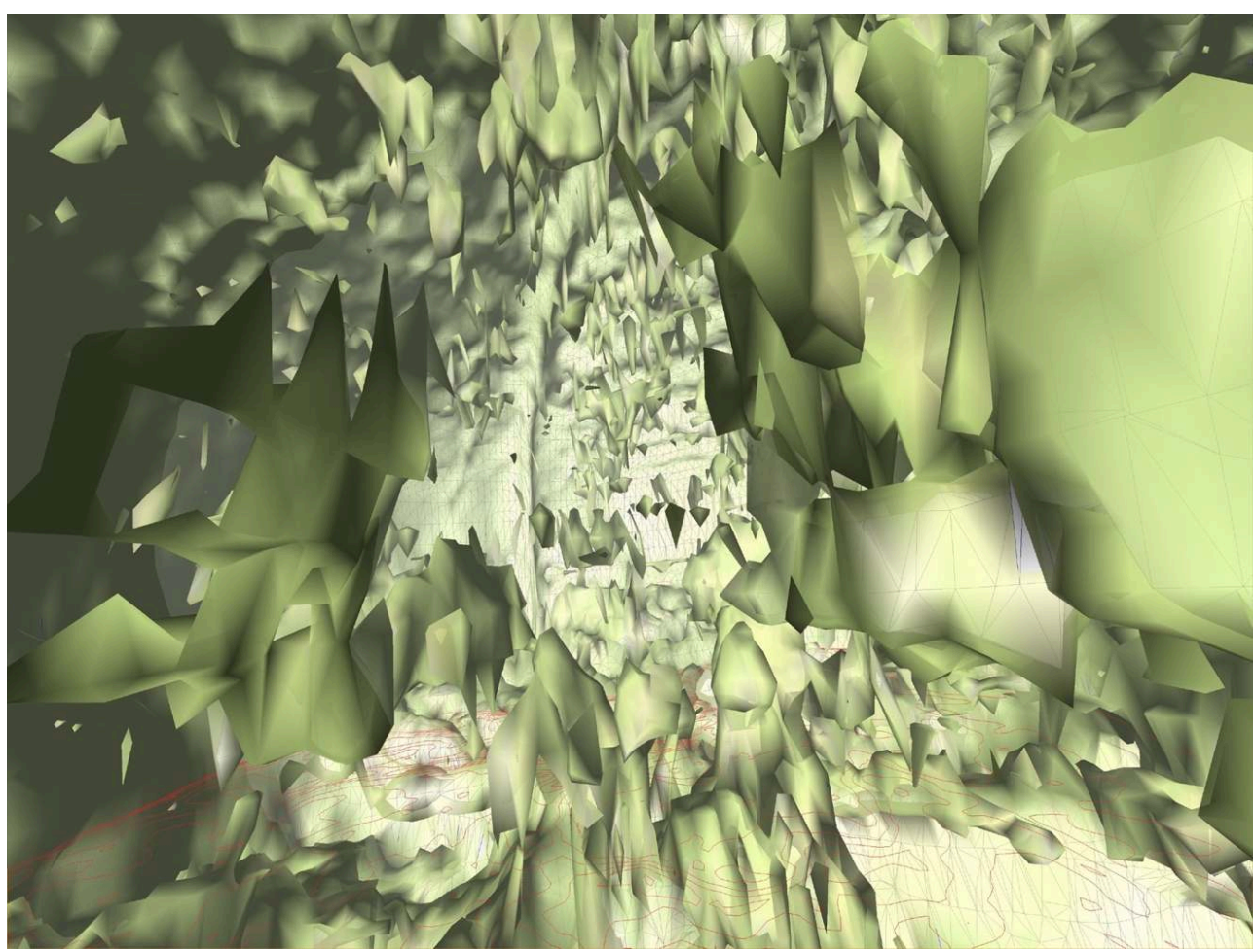

Source: Kuchera-Morin (2009a). http://www.sweetspeeches.com/s/191-joann-kuchera-morinstunning-data-visualization-in-the-allosphere 
Figure 3: The design of AlloSphere

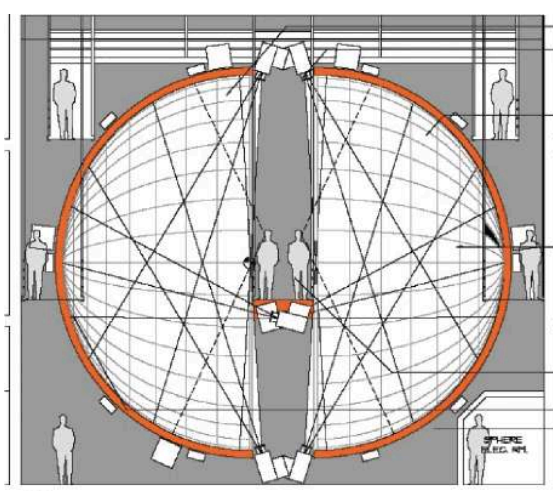

(a)

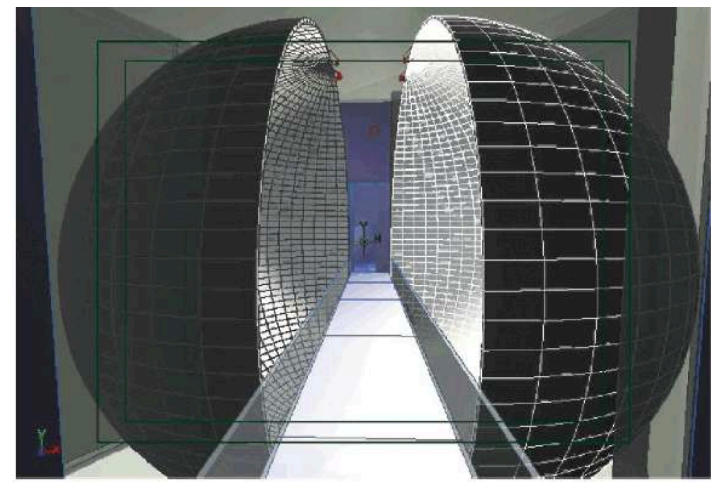

(b)

Source: Kuchera-Morin (2009b)

\section{An uncanny portrait}

AlloBrain constitutes a very special kind of self-portrait. Rather than a conventional representation of the surface and the skin of the artist, it enables us to plunge directly and physically into the architect's head. The intention of Eduction was to externalise the mental space of a volunteer to share it with viewers, drawing a movement from the inside to the outside. With AlloBrain, this movement is reversed, permitting to enter a three-dimensional immersive model of a human brain, of Novak's cerebral space. Thus it is not an "esoscope" as with Dancing with the Virtual Dervish and Eduction: it is an "endoscope". The aim is not to explore "esospaces", the spaces of the self, but "endospaces", that is to say, in this case, the unfamiliar and invisible inner-brain territories. While traditional self-portraits allow the artist to see him/herself as another person sees him/her, to borrow his/her gaze in a doubling by which, and through reflection, s/he can objectify him/herself - that is to say grasp his/her identity in terms of sameness and otherness - AlloBrain operates an "unfacing," to borrow one of Gilles Deleuze and Félix Guattari's expressions: an unveiling or an "unconcealment" of what is hidden behind Novak's face. If the portrait is "on the edge of a material world and another intangible", if "it is in between a reality where everything is measurable and the space of a dream in which no aberration is no longer irrefutable" (Bonafoux, 2004: 41), what AlloBrain exposes is the uncovering of a strangeness, an uncanny feeling that invaginates everyone who experiences this immersive environment.

Thus AlloBrain exhibits, and this exhibition does not only concern the architect but each of us, since we all have a brain that is a priori structured in the same way. Yet, in this portrait, we do not recognise ourselves or find ourselves. We have to deal with something about unknown territories of the body, about an anonymous and subterranean singularity which is nevertheless present in all of us, something like a monstrous face, a "non-face" which exceeds language. Therefore, in my opinion, AlloBrain is an "explicitation" work in which what is unfolded seems to relate to a particular monstrosity. The term "explicitation," from the Latin explicare, means "to unfold", "to unravel", "to explain" and refers to the act of informing, bringing forward what was kept implied, making known what was unknown while being latent. In Foams, the last volume of the Spheres trilogy, German philosopher Peter Sloterdijk writes that: 
"Not only explicitations make explicit unspoken and underlying assumptions ('unconscious', unknown, misunderstood), but they raise 'realities' so far hidden in the folds of the latency at the level of apparent existence." (2005: 184-185). In this perspective, AlloBrain appears to me as a setting in picture of a monstrous Unheimliche because something does not make sense. But what is it that does not make sense? And why did an uncanny feeling take possession of me when I experienced AlloBrain? I would like to answer this question in a summarised, and yet almost obvious, way: because of the way the psyche itself works.

\section{Physicality and the Mind-body problem}

13 How is it possible that, out of the brain, out of a material organisation, however complex it may be, something like consciousness may emerge? This question is central to neuroscience and cognitive science, whose project is to give a "materialist explanation of the mind" (Le Blanc, 2014: 102), particularly in its cognitive dimension. For these research fields, a project of the "naturalisation of man" is undertaken, making man "an animal like the others", as suggested by French philosopher Francis Wolff (2010: 131-132). Through this naturalisation, scientists try to make man fully explainable by his material foundations, any feature that would be owned exclusively by man is erased, any strangeness irreducible to the rest of the living brushed away, which results in the removal of all boundaries between man, animal and, of course, machine. There would be no "ghost in the machine," in the words of Gilbert Ryle (2002). There would be no enigma or mystery of the mind. As suggested by neuropsychiatrist and neurobiologist Jean-Didier Vincent, physicalism - i.e. considering that absolutely everything in man, as in everything else, is reducible to physical properties, or that nothing exists beyond the material -, "fed successively by pharmacology, molecular biology, neuroinformatics and finally by brain imaging, took the psyche, now lost heart and soul in neural networks." (2007: 30). In short, consciousness would be merely an emergence of matter organized in a complex manner, whether organic, artificial, digital, or made of silicon.

Consciousness would only be a mere epiphenomenon resulting from physiochemical phenomena occurring in the brain, the brain itself being a mere neuron system. For cognitivists, the mind and mental processes could be defined as simple information processing whose matrix is the brain. The brain would function like a computer and the mind would be a software program, a series of algorithms. In his book L'homme neuronal, French neurobiologist Jean-Pierre Changeux argued that "it is enough to say that consciousness is a regulation operating system. Man has therefore nothing to do with the 'Spirit,' he only needs to be a Neuronal Man." (1983: 211) On this new concept of the neuronal man, Wolff declared:

$[\mathrm{M}] \mathrm{an}$ is a natural being, like all the others; it is an animal, no more no less. Not only has man no essence [...], and therefore all barriers that once enclosed him in essence should be abolished, but he even does not have a proper being - that is what constitutes the originality of this new figure. For the first time, science studies man itself assuming that none of its properties fundamentally distinguishes him from other natural beings, or even from some artificial beings. (2010: 131-132)

Consequently, one could reproduce the emergence of consciousness in silico. That is the purpose of strong artificial intelligence proponents, which try to provide machines with intelligence, that is to say with the ability to reason logically, ${ }^{4}$ but also with 
psychological awareness and phenomenal consciousness. ${ }^{5}$ According to Australian philosopher and cognitive scientist David Chalmers, psychological awareness refers to the ability to know one's internal states as well as those of one's environment, while phenomenal consciousness refers to the capacity to experience these states in the first person ("I") (1996: 25-31). The strong artificial intelligence project is therefore trying to create machines possessing all human behaviours and abilities, or even able to exceed them, leading to the much-talked-about fear of a competition between machines and mankind, which would lead to the latter's outright extinction. This idea can be found in the notorious transhumanist interviews and texts with Kevin Warwick. According to him, "The way things are going, it is soon [the computer] that will make the decisions, not us. If we want to maintain our edge, we must progress at the same pace. Technology may turn against us. Unless we merge with it." (Cited in Boltanski, 2002).

\section{Phenomenal consciousness, subjective experience and the living flesh}

The same idea motivates the mind-uploading project defended by researchers in Artificial Intelligence such as Hans Moravec, Ray Kurzweil or Marvin Minsky. ${ }^{6}$ For them, the mind or the brain itself, reduced to its content, could be downloaded online or in a computer, ridding it of its flesh and of its finitude. To go back to AlloBrain, it seems at first that we deal with the same reduction as cognitive science operates, describing the mind as a by-product of the brain. But we witness a major shift in the thought of Marcos Novak when we compare AlloBrain to Dancing with the Virtual Dervish. While in the latter project, the architect proposed to recognize the physicality of the mind, that the mind makes the body, questioning the meanders of our interiorities, with AlloBrain the pattern seems to be reversed. Is this not a project trying to explain the mind by mere brain matter? The interior that is given to explore is not that of the mind or the consciousness but, very strictly, that of the brain. Thus, is not interiority in itself erased? What appears to me as properly monstrous is that what is exposed to our view is not phenomenological flesh, living and lived-in flesh, but a brain without a body, without flesh, a bare and digitally-reconstructed inside that appears empty of interiority. Consequently, it is impossible to recognize ourselves in it. Therefore, what is questioned is the impossible, the unspeakable, the indescribable that makes man man, as can be seen and lived only by him.

17 Interestingly, Jean-Didier Vincent states that "the brain is the scream of the flesh!" (Atlan, Droit, 2012: 179), and AlloBrain, as an immersive environment, is indeed a lived environment, and one that is lived in the first person, to boot. This "I," this phenomenal, subjective and embodied consciousness, goes into ecstasy, suffers, feels disgust and shame, says "no," exists, resists being reduced to a brain, however complex and what's more, resists any explanation:

If the physical structure of reality - the particle distribution, the force fields in space-time - is logically consistent with the absence of consciousness, so something resists explanation. The presence of consciousness would be a supplement, an extra compared to the world. And on this point, we must recognize that, at present, there is no valid answer. (Atlan, Droit, 2012: 208) [consciousness], but we do not even know what an explanation would be." (2010: 352). 
Thereby, the uncanny effect produced by the immersion in AlloBrain seems to me to result from this confrontation between phenomenal consciousness and representation in which we are immersed: a digital reconstruction of a material brain that, firstly, is inside us, is ours, but appears to us as strange and bizarre; secondly, that only offers us an "unreasonable silence," in the words of Albert Camus (1942: 42), that is to say, an absence of response to the question of the "why" of consciousness.

Indeed, I think that it is the question of the "why" - and not that of the "how" which neuroscience and cognitive science try to solve - that Marcos Novak explores in this project: the why of interiority, of a psyche, a consciousness that does not make sense with a simple neuron system. Even if they emerge naturally through this complex material organisation, nothing tells us why they actually emerge. This obscurity, this unanswered question, gives rise to the absurd which is not necessarily a dereliction, but rather an amazement, recognising that we still resist, that something like this phenomenal and subjective "I" - that, if inexplicable, is not less than that through which we experience the world, by which we are in the world, by which we exist - is the fact of a life that traverses the body and is totally attached to it, a life of which we certainly know the "how" (biological evolution) but of which the "why" remains indefinite, mysterious. What, then, is the purpose of AlloBrain? What does AlloBrain induce? I think that this environment allows us to return to the physical body, to the lived and living flesh, focusing on a body that nonetheless is foreign to us. For there is always something resisting, and that thing which resists and is not captured by digitisation, the thing that causes the uncanny feeling, may be the "I" itself, the "I" by which we experiment our body as well as the world.

\section{To have a body/to be a body: mind-uploading as an abandonment of the world?}

Let's return to the question of mind-uploading. Supporters of this project consider that we could upload ourselves in the computer and still remain absolutely the same. In fact, Marvin Minsky, Hans Moravec and others appear to underestimate - in a quite radical way - how our bodies are involved in the construction of our identities. They consider that economising the materiality of the body does not change who we are. But not only do I have a body like I would have a tool, I am a body! My body is me, entirely. The "I" and the body, the body as Leib, the living flesh, are intimately intertwined, and it is only by this interlacing that I am in the world, that I can experience it, that I can participate in the world and in its life. Thus, when transhumanists talk about abandoning the flesh, this "meat" that is a burden to them, are they not voicing the "fatigue of being," in the words of Alain Ehrenberg (2000) or Jean-Michel Besnier (2009)? Is not mind-uploading a project that is actually leading to the abandonment of the world? These are rhetorical questions, no doubt. In my view, the mind-uploading fantasy is just one of the latest figures in a crisis of dwelling already denounced by German philosopher Martin Heidegger in 1946 and then by Sloterdijk, among others. This crisis impacts our being in the world as well as our inhabitation of the body, as our being in the world is intrinsically embodied. This story is profoundly linked to that of the disenchantment of the world, going back much further than the twentieth century, and even beyond the three narcissistic wounds identified by Freud. ${ }^{7}$ 
Within a disenchanted world, without a stable ground on which to be anchored, the "extremist transhumanists" wish to set sail in the ocean of information, in the immaterial data networks. They want to leave the world and the body by which they have been related to the world, leaving out what made them men, fleeing the human condition. The transhumanist dream is utopian, perhaps even dystopian. Nonetheless, its radicalism is symptomatic. As Fréderic Neyrat argues: "the contemporary subject lives exposed, he does no longer know if he lacks an Outside world or, more cruelly but symmetrically - an Inside one, an inhabitable interior worthy of the name." (Neyrat, 2006). Undoubtedly cybernetics has participated in this hesitation, through the denial of interiority that it promoted, and through the development of cognitive science and neuroscience it carried with it, which seem imbued with the same refusal of the notion of insideness. The body "hides a strange depth that is bound up with the unconscious, with the animality that is inside us, with this discharge part that does not find meaning in cybernetics." (Coulombe, 2009: 44-45). In our digital era, the body, the unconscious and consciousness, all that we traditionally use to define humankind, no longer make sense. But have they ever made sense?

\section{Conclusion}

A brain without a body: what a strange proposal! In his seminal essay on "The Uncanny", Freud stated that the spectacle of severed limbs waving in every direction as independent parties, provoked one of the strongest feelings of the uncanny $(1919,2003$ : 150). AlloBrain goes further. By making us experience the inside of a cerebral space, making us enter it as if we were penetrating a new world, engaging our full bodies, it helps us contemplate one of the most intriguing questions that men have asked themselves, if not one of the most intriguing questions. Why are we what we are? Why are we conscious of what we are, with our flesh, under the sky and on the ground of this world, saying "I", living in the first person? Here lies the uncanniness of a project such as AlloBrain@AlloSphere. If the human condition can be absurd, let's dare to make one last statement: we are human because we have and are a body. That is not to say that by uploading our minds or our brains in networks we will no longer be human. It would be disregarding the fact that, as Henri Atlan said, "nobody really knows what [t]he idea of Man, with a capital M, refers to," (in Atlan and Droit: 78-79) or, in the words of Atlan and Droit:

[T] he only worthwhile definition [of the human being] is known, and it is not going very far. It essentially says that man is a blank page, the only living being to build, to confront the void that constitutes him and in which he has to write a story that is known by no one, and certainly not by him, before he invents it. (2012: 10)

This is why I believe the issue of posthumanity is entirely based on an illusion. The idea of an end of the human, indicated by the prefix "post-," of an exit of the human species or a rupture with it, suggests that there is a humanity which it would be possible to transcend. If there is no longer such a thing as Man but only a "becoming human," the danger is not that of a disappearance of humanity but of inhumanity, which is consubstantial to man, "the human species proper" according to Atlan (2007: 22-23). Transhumanists are looking towards posthumanity, but at the end of the road, there is no posthuman, only the inhuman. 


\section{BIBLIOGRAPHY}

Atlan, Henri. "Les frontières revisitées". Les frontières de l'humain. Henri Atlan and Frans de Waal. Paris: Le Pommier/Cité des sciences et de l'industrie, 2007. 5-51.

Atlan, Monique, and Roger-Pol Droit. Humain : une enquête philosophique sur ces révolutions qui changent nos vies. Paris: Flammarion, 2012.

Besnier, Jean-Michel. Demain les posthumains : Le futur a-t-il encore besoin de nous ? Paris: Hachette, 2009.

Boltanski, Christophe. “Kevin Warwick, l' Homo Machinus”. Libération, 11 May 2002. https:// www.liberation.fr/week-end/2002/05/11/kevin-warwick-1-homo-machinus_403267

Bonafoux, Pascal. Moi ! Autoportraits du XXe siècle. Milan: Skira, 2004.

Camus, Albert. Le Mythe de Sisyphe : essai sur l'absurde. Paris: Gallimard, 1942.

Chalmers, David. The Conscious Mind: In Search of a Fundamental Theory. New York: Oxford UP, 1996. Changeux, Jean-Pierre. L'homme neuronal. Paris: Fayard, 1983.

Coulombe, Maxime. Imaginer le posthumain, sociologie de l'art et archéologie d'un vertige. Québec: PU de Laval, 2009.

Deleuze, Gilles, and Félix Guattari. Capitalisme et schizophrénie 2 : Mille Plateaux. Paris: Les Éditions de Minuit, 1980.

Ehrenberg, Alain. La Fatigue d'être soi. Dépression et société. Paris: Odile Jacob, 2000.

Freud, Sigmund. “The Uncanny” (1919). The Uncanny. London: Penguin Books, 2003. 121-162.

Garcia Lorca, Federico. "Theory and Play of the Duende" (1930). Trans. A. S. Kline. Project Gutenberg Self-Publishing Press, 2007. http://uploads.worldlibrary.net/uploads/pdf/ 20121106215225lorcaduendepdf_pdf.pdf

Heidegger, Martin. "Letter on Humanism" (1946). Basic Writings: Martin Heidegger. London: Routledge, 2010 (1977). 141-182.

Jentsch, Ernst. On the Psychology of the Uncanny. Sl: sn, 1906.

Kuchera-Morin, JoAnn. "Stunning Data Visualization in the AlloSphere". TED2009: The Great Unveiling, February 2009a. https://www.ted.com/talks/

joann_kuchera_morin_stunning_data_visualization_in_the_allosphere/transcript?language=en

Kuchera-Morin, JoAnn, Xavier Amatriain, Tobias Hollerer, and Stephen Travis Pope. "The AlloSphere: Immersive Multimedia for Scientific Discovery and Artistic Exploration". IEEE MultiMedia 16.2 (April-June 2009b). 64-75. DOI: 10.1109/MMUL.2009.35

Lacan, Jacques. Le Séminaire XVI. D'un Autre à l'autre (1968-1969). Paris: Seuil, 2006.

Le Blanc, Benoît. “La (non) place de l'altérité dans les sciences cognitives”. Hermès, La Revue 68 (2014). 102-105. https://www.cairn.info/revue-hermes-la-revue-2014-1-page-102.htm

Lestel, Dominique. "Des enjeux de la tentation posthumaine”. Technocorps : La sociologie du corps à l'épreuve des nouvelles technologies. Ed. Brigitte Munier. Lormont: François Bourrin, 2013. 145-170. 
Lutyens, Marcos. “Eduction Erice, Italy, 2001”. Marcos Lutyens, 2001. [archive: https:// web.archive.org/web/20170624051156/http://www.mlutyens.com/dr-cold-weather,-jausgallery,-santa-monica,-ca-2012.html\#.WU30ofLgpTY]

MacRobert, Laurie. Char Davies's Immersive Virtual Art and the Essence of Spatiality. Toronto: U. of Toronto P., 2007.

Minsky, Marvin. The Emotion Machine. New York: Simon and Schuster, 2006.

Neyrat, Frédéric. "La vie dans les sphères : comment vivre dans un oikos éclaté ?" Multitudes 24 (2006). https://www.multitudes.net/la-vie-dans-les-spheres-comment2352/

Novak, Marcos. "Alloaesthetics and Neuroaesthetics: Travels through Phenomenology and Neurophysiology". ArtBrain, Journal of Neuro-Aesthetic Theory, 2005. https://www.artbrain.org/ alloaesthetics-and-neuroaesthetics-travels-through-phenomenology-and-neurophysiology/ Novak, Marcos. "2004 World Technology Awards Winners \& Finalists”. The World Technology Network, 2004. https://ftpwtn.b.civicrm.ca/2004/bio212.html

Novak, Marcos. "Dancing with the Virtual Dervish: Worlds in Progress". Immersed in technology, art and virtual environments. Eds. Marie Ann Moser and Douglas Macleod. Cambridge: The MIT Press, 1996. 303-8.

Novak, Marcos. "Liquid Architectures in Cyberspace". Cyberspace: First Steps. Ed. Michael Benedikt. Cambridge: The MIT Press, 1992 (1991). 225-254.

Palumbo, Marialuisa. “Eduction. Design by Algorithm”. arch'it 2001. http://architettura.it/ extended/20011228/index_en.htm

Ryle, Gilbert. The Concept of Mind. Chicago: U. of Chicago P., [1949] 2002.

Simon Herbert A. The Sciences of the Artificial. Cambridge and London: MIT Press, [1969] 1996.

Shannon, Claude E. "Communication Theory of Secrecy Systems." Bell System Technical Journal 28:4 (Oct 1949): 656-715. DOI: 10.1002/j.1538-7305.1949.tb00928.x

Spiller, Neil. “It's all inside my head.” AD Architectural Design 77.4 (2007): 118-9. DOI: 10.1002/ad. 497

Sloterdijk, Peter. Écumes. Paris: Maren Sell, 2005.

Taleb, Mohamed. "Crise des sciences, retour au mythe et appel de l'Être. Entretien avec Anne Perol." Sciences et archétypes, Fragments philosophiques pour un réenchantement du monde. Ed. Mohamed Taleb. Paris: Éditions Dervy, 2002. 139-168.

Turing, Alan M. “Computing machinery and intelligence”. Mind 59.236 (1950): 433-460. DOI: 10.1093/mind/LIX.236.433

Vincent, Jean-Didier. Voyage extraordinaire au centre du cerveau. Paris: Odile Jacob, 2007.

Von Neumann, John. The Computer and the Brain. Yale: Yale UP, [1958] 2000.

Wakefield, Graham, et al. "The AlloBrain: an Interactive Stereographic, 3D Audio Immersive Environment". International Journal of Human Computer Studies 67.11 (2009). https:// www.mat.ucsb.edu/Publications/08_Wakefield_SIDCHI_AlloBrain.pdf Wiener, Norbert. The Human Use of Human Beings: Cybernetics and Society. London: Free Association Books, 1989 (1950).

Wolff, Francis. Notre humanité. D’Aristote aux neurosciences. Paris: Fayard, 2010. 


\section{NOTES}

1. This conference was held at the Villa San Giovanni, 28 June - 1 July 2001. More information is available online at: http://www.psychiatryonline.it/node/2580.

2. In Spanish mythology, the duende is a fairy or goblin-like creature. According to Lorca, it is a spirit which is revealed in the practice of dance, song, recited poetry, flamenco or tauromachy. (2007)

3. More information on the Brain Mapping Center is available online at: http:// www.bmap.ucla.edu.

4. From Latin intellegere, intelligence means the faculty of understanding, of discerning or of forging representations and manipulating them logically, that is to say reasoning. For the pioneers of artificial intelligence (John von Neumann, Norbert Wiener, Claude Shannon, Alan Turing, Herbert Simon, Marvin Minsky, etc.) - a research field developed in the 1950s intelligence, reasoning faculty, has been reduced to a calculation ("reason" comes from the Latin ratio, which means "calculation"), to a program that can operate regardless of its support, organic or made of silicone. The pioneer, Alan Turing published in 1950 the article "Computing Machinery and Intelligence", in the journal Mind, exposing the experiment called the "Turing test". In 1951, he also gave a conference for the BBC entitled "Can Digital Computers Think?"

5. Strong artificial intelligence project differs from the soft artificial intelligence one in that the latter produce machines or computer programs roughly simulating intelligence, acting as if they were intelligent.

6. Interestingly, the idea of mind-uploading was already present in the thought of the famous father of cybernetics, Norbert Wiener. In The Human Use of Human Beings, he wrote: "It is amusing as well as instructive to consider what would happen if we were to transmit the whole pattern of the human body, of the human brain with its memories and cross connections, so that a hypothetical receiving instrument could re-embody these messages in appropriate matter, capable of continuing the processes already in the body and the mind, and of maintaining the integrity needed for this continuation by a process of homeostasis." (1989: 96) A few pages later, he added: "the fact that we cannot telegraph the pattern of a man from one place to another seems to be due to technical difficulties [...]. The idea itself is highly plausible." (1989: 103-104).

7. "The disenchantment of the world, the loss of standards and the decline of the sense are not to me unavoidable consequences of scientific progress in itself but the result of a much older renunciation of the whole by man. This same denial is the cause of forgetfulness of Being. By his creative will, which was simultaneously a rupture, somehow man extracted himself from the world; he has lost its place and its base within it. This is what it means to forget the Being: losing place in the harmony of the world. It was probably the condition of its entry into history, the price to pay for this wonderful adventure of domination, and somehow in the best case, the conscious creation by man of the manifested world. But now, weaned off forces of life, deaf to the voice of nature, contemptuous of the energy of dreams, man is divorcing with his original world and thus deprived of real reasons to live in it." (Perol, in Taleb, 2002: 157)

\section{ABSTRACTS}

Since the early 1990s, the architect and artist Marcos Novak has been developing an experimental and transdisciplinary practice at a point of convergence between architecture, art, 
science, technology and philosophy, questioning the becoming of the digitally-enhanced body. With AlloBrain@AlloSphere, a virtual reality environment developed between 2005 and 2009 with the support of the Brain Mapping Center (University of California, Los Angeles), Novak proposes an immersive exploration of our brain spaces. AlloBrain is modelled from brain MRIs, extruded in the form of a three-dimensional volume. The experience offered is that of an immersion inside our heads. However, in this way of looking beyond the face, we find it hard to recognise ourselves. Projections or exteriorisations of a hidden interiority, the showing of these unknown territories of the body, of this anonymous and subterranean singularity, arouse an uncanny feeling in us. The explored interior is not that of the mind or of consciousness but, very strictly, that of the brain, more precisely that of a brain without a body, without flesh, a bare and digitally reconstructed enclosed space that yet appears empty of interiority. Are we dealing with a project that tries to explain the mind by mere brain matter, similar to the cognitive sciences or neurosciences? Still, the effect of uncanniness produced by the immersion in AlloBrain seems to result from the confrontation between this "naked brain" and our subjective experience, which seems unable to dispose of the physical body we inhabit and that inhabits us, too. Thus, what AlloBrain causes is a real return to the flesh, a lived-in and living flesh, highlighting a particularity that is nonetheless alien to us, because in reality something always resists. It not the thing that cannot be captured by digitisation the phenomenal "I" itself, the "I" by which we experience our body and the world? Such a hypothesis would give us ground to doubt that by avoiding the materiality of the body, by uploading our minds in the machine, we could remain the same.

Marcos Novak, architecte et artiste, développe depuis trente ans une pratique expérimentale et transdisciplinaire au point de rencontre entre architecture, art, sciences, nouvelles technologies et philosophie, interrogeant les devenirs du corps augmenté par le numérique. Dans l'environnement de réalité virtuelle AlloBrain@AlloSphere (2005-2009), élaboré avec l'aide du Brain Mapping Center de l'Université de Los Angeles en Californie, Novak propose une exploration immersive de nos espaces cérébraux. Environnement immersif modélisé à partir d'IRMs cérébraux extrudés sous la forme d'un volume tridimensionnel, l'expérience d'AlloBrain est bien celle d'une plongée à l'intérieur même de notre crâne. Dans cette percée au-delà du visage, nous peinons cependant à nous reconnaître. Projections ou extériorisations d'une intériorité dissimulée, la monstration de ces territoires inconnus du corps, de cette singularité anonyme et souterraine, éveillent en nous le sentiment d'une inquiétante étrangeté. L'intérieur qui nous est ici donné à explorer n'est pas celui de l'esprit ou de la conscience mais celui, très proprement, du cerveau, plus encore d'un cerveau sans corps, sans chair, un dedans dénudé et numériquement reconstruit, un espace qui, s'il est bien intérieur, semble vide d'intériorité. N'avons-nous pas là affaire à un projet d'explicitation du mental par la seule matière cérébrale, similaire à celui des sciences cognitives ou des neurosciences? Quoi qu'il en soit, l'effet d'étrangeté que produit l'immersion dans AlloBrain nous semble résulter de la confrontation entre ce cerveau nu et l'expérience subjective, laquelle paraît ne pouvoir se départir d'un corps physique, corps que nous habitons autant qu'il nous habite. Ainsi, c'est un véritable retour à la chair, cette chair vivante et vécue, que provoque AlloBrain, soulignant un propre qui nous est pourtant étranger. Car toujours, quelque chose résiste. Cette chose-là, cette chose qui ne peut être saisie par la numérisation, n'est-ce pas le «Je » phénoménal lui-même, ce « Je » par lequel nous faisons l'épreuve de notre corps comme du monde? N'y a-t-il pas là de quoi mettre en doute qu'en nous téléchargeant dans la machine, qu'en faisant l'économie de la matérialité du corps, nous puissions rester les mêmes? 


\section{INDEX}

Mots-clés: corps-esprit, réalité virtuelle, inquiétante étrangeté, expérience subjective, conscience phénoménale

Keywords: mind-body, virtual reality, uncanny, subjective experience, phenomenal consciousness

\section{AUTHOR}

\section{MARION ROUSSEL}

Marion Roussel is an architect an a PhD in architecture. She is also a member of the steering committee of DNArchi.fr, a publication website about digital culture and digital architecture. Her recent publications include: "De l'androïde à l'avatar : chairs étranges du cinéma de sciencefiction au XXe siècle", in Les représentations troublées des corps au cinema, eds. Sophie Walon, Jérôme Bloch and Benjamin Flores, Paris: L'Harmattan (forthcoming in 2016); "L'architecture évolutionnaire. De la génétique en architecture”, DNArchi, May 2014. http://dnarchi.fr/culture/ larchitecture-evolutionnaire-de-la-genetique-en-architecture/; "Habiter l'immatériel ou l'architecture du cyberspace", in Les Cahiers Européens de l'Imaginaire 6 (2014): 264-5; “Devenirliquide, devenir-alien. Des devenirs-autres des corps dans l'architecture de Marcos Novak", Le Philotope 10 (2014): 149-153. Contact: roussel.marion [at] hotmail.fr 